\title{
Addressing Islamic Values in Medical Imaging Professionalism
}

\author{
Siti Maryam Muhamad Ruzlan ${ }^{1}$ and Zainul Ibrahim Zainuddin ${ }^{2}$ \\ ${ }^{1}$ Department of Diagnostic Imaging and Radiotherapy, ${ }^{2}$ Kulliyyah of Allied Health Sciences, International \\ Islamic University Malaysia Kuantan Campus, Jalan Sultan Ahmad Shah,25200 Kuantan, Pahang, Malaysia.
}

\section{ABSTRACT}

This paper presents a conceptual framework in aligning the integration of Islamic values into the Medical imaging practices through the aspect of Islamic Personality (IP). IP is a form of moral quality in the psychological aspects of a human, which is governed by the belief in Allah as the One God and Prophet Muhammad (Peace be upon him) as His servant and His messenger. This work is seen within the context of harmonizing Islamic values to the currently accepted professional attributes in medical imaging. The medical imaging practice is comprised of various domains; basic principles in healthcare and medical imaging, patient care, use of technology, the technicalities or procedures, quality, safety, economic, research and professionalism. In order to conceptualize the IP as applicable for Muslim Medical imaging practitioners' ten professional guidelines were examined. The extracted professional attributes were sorted into common themes within the context of the above domains. From the examination of the guidelines, the expected professional attributes of medical imaging practitioners are closely related to the concepts in Islamic ethics ('ilm al-akhlaq) and circle around character building. There are nineteen common professional personality traits that were determined from the Medical imaging professional guidelines; 1) respectful, 2) safe practice, 3) safe activity, 4) equality, 5) trustworthy, 6) honesty and integrity, 7) truthful, 8) responsible and accountable, 9) compassionate, 10) wisdom, and 11) being up-to-date, 12) competence, 13) teamwork, 14) self-reflection, 15) dignity, 16) ethical behaviors, 17) adhere to laws and regulations, 18) effective communication, and 19) continuity of knowledge and skills development. Some of these traits were interpreted within the Islamic perspectives as applicable for Muslim Medical imaging practitioners. The outlined conceptual framework could be a model for improvement in the practice of Muslim Medical imaging practitioners in terms of IP. In conclusion, the professional attributes as addressed in the current professional guidelines are feasible to be aligned with the IP to form a set of Islamic personalities that are applicable for Muslim Medical imaging practitioners.

KEYWORDS: Islamic values; Islamic Personality; Medical imaging; Professional attributes; Islamic ethics.

\section{INTRODUCTION}

Islamic personality (IP) is a form of moral quality in the psychological aspect of a human, which is governed by the belief in Allah as the One God and Prophet Muhammad (Peace be upon him) as His servant and His messenger. Islamic beliefs, values, morals and practices form the other branches of Islamic heritage that champion the good and oppose the evil. These elements are incomplete if they are separated from each other since the Islamic belief necessitates for the good and right practices in all aspects of life.

The belief in Allah and the Prophet will not be perfected without the beautification of the character. In other words, a Muslim who has the true faith must manifest the good character in each aspect of his daily life. Good character composes all the moral values that guide one in what to do and what not to do. Primarily, characteristics of good

Zainul Ibrahim Zainuddin

Kulliyyah of Allied Health Sciences,

International Islamic University Malaysia,

Kuantan Campus.

Email: zainul@iium.edu.my character from the Islamic perspective come from two main sources; the Holy Qur'an and the traditions (Sunnah) of Prophet Muhammad (Peace be upon him).

In Islam, there is no separation between religion and moral values, for moral values are already imbued within the Islamic teaching itself. Faith is only genuine if it results in moral behaviour since moral behaviour is the fruit of true faith...-1,2 Furthermore, it is manifested in the Holy Qur'an in chapter 6, verse 162, "Say: 'Truly, my prayer, and my service of sacrifice, my life and my death, are (all) for Allah, the Cherisher of the Worlds'." ${ }^{3}$ This shows the bond between the religion and morality in life matter.

Currently, the realization of IP aspects is still lacking in the Medical Imaging practices. This has been stressed in a study by Zainuddin. ${ }^{4}$ The author explains that this is one of the consequences of the adoption of secular approach in separating spiritual dimensions from medical imaging practices. Negative effects may occur to the Medical imaging practices in particular, and the healthcare practices in general. For example, the absence of the 
understanding and application of the concept of amanah (trustworthiness) in any field of healthcare practices may cause the violation of the patient's right, especially when the authority is not there or the patients are unaware of their rights.

Medical Imaging or Radiography is a subspecialisation in the field of Medicine. It is concerned with the production of images of the human anatomy. A Medical Imaging practitioner or professional is also known as Radiographer or Radiologic Technologist .This refers to the professional who uses medical imaging equipment for the diagnosis, monitoring, and treatment of disease processes. The domains in Medical imaging include basic principles in medical imaging, patient care, use of technology, the technicalities or procedures, quality, safety, economic, research and professionalism. Specific professional qualities are needed in order to ensure the desirable conduct in these different domains.

A professional guideline is a written document that lists the best practices for a particular profession in a given country. It is provided to guide and support the practitioners in the practice of their profession. Existing Medical Imaging professional guidelines do address the attributes that are applicable to the practitioners. However, those guidelines do not denote the obligations within the scope of religion that is practiced by a Muslim Medical Imaging practitioner. This can reduce the effectiveness of the professional practices among the Muslim Medical Imaging practitioners in deciding the most appropriate way for example, when managing the ethical dimensions in their professional settings from the religious point of view.

The ethical issues in the medical imaging practices such as the violation of the patients' rights, the misuses of medical imaging equipment, and the misconduct of the examination procedures will cause the deterioration of the professional practices in the discipline. This could have negative implications upon the patient, the practitioner, other healthcare practitioners and the administration. A Muslim practitioner must have the capability to incorporate the principles in the religion into their professional practices. Ethical issues that arise from time to time and their subsequent interpretations are among the problems within the Medical imaging professional settings. One of the methods to manage the ethical issues arising in this field is by internalizing the Islamic personality within the Medical Imaging practitioners themselves. The Islamic personality in medical imaging must be specific and it should cover all aspects in the medical imaging professional settings. However, at present the Islamic personality aspects in Medical imaging are still unspecified.

The current study aims to conceptualize the Islamic personality aspects for Medical Imaging practitioners with respect to the domains in Medical
Imaging. The sources of the expected personality aspects were extracted from professional guidelines and literatures of Medical Imaging practice. The extraction process was done by sorting out the common professional attributes within those guidelines into several themes. The themes were then used to identify the Islamic personality traits that are within the specific context of the domains in Medical Imaging. The results were tabulated for easy appreciation. However, due to space constrains only a few professional traits were discussed in terms of infusing the Islamic values. For the purpose of this paper Qur'aanic translations by Abdullah Yusof Ali were used.

It is anticipated that findings of the study will pave the way for the improvement in Medical Imaging practices, seen within the Islamic perspective. The professional attributes for the Muslim Medical imaging practitioners must be incorporated with the Islamic belief, values, morals and practices that form the branches of Islamic heritage. It is expected that the criteria of the Islamic personality traits as applicable to Muslim Medical imaging practitioners will be beneficial for the development of a more specific tool for Islamic personality, applicable for Muslim Medical imaging practitioners in the future. The existence of a specific set of Islamic personality for Muslim Medical imaging practitioners will help them in the introspection process and the display of Islamic attributes in their professional environment.

\section{Overview of Personality and Character}

Personality can be understood as the traits that are imbued within a person that eventually govern his behaviour, thoughts and feelings. Merriam Webster Dictionary defines personality as (I) the set of emotional qualities, ways of behaving, etc., that makes a person different from other people, (ii) attractive qualities (such as energy, friendliness, and humour) that make a person interesting or pleasant to be with, (iii) attractive qualities that make something unusual or interesting (http://www.merriamwebster.com/dictionary/char acter). All port opines that personality is an inner system that is related to physics of psychology. ${ }^{5}$ It is dynamic and it forms the pattern of attribute of a person in terms of his actions, thoughts and feelings. Maddi defines personality as a set of attributes and inclinations which are stable. ${ }^{6}$ It controls the psychological behaviour (thoughts, feelings and actions) of people that are connected with time and might not be understood easily because of the social and biological burdens at the given moment. The understanding about personality is further made complicated when personality is correlated with the environment as the behaviour of a person can change, attributed to the surrounding factors. ${ }^{7}$ This is supported by Zidan, who argues that personality is shaped by the situation faced by a person and eventually becomes a norm. ${ }^{8}$ It can be concluded that personality is a set of attributes that are shaped by the surrounding factors that eventually become stable. 
The Merriam Webster dictionary defines character as (i) the way someone thinks, feels, and behaves: someone's personality, (ii) a set of qualities that are shared by many people in a group, country, etc. (iii) a set of qualities that make a place or thing different from other places or things. (http://www.merriamwebster.com/dictionary/char acter). Ashbrook states that the term "character" was cited early by the Greek philosopher Theophrastus (372-287 B.C.) who introduced 30 types of characters that are comparable to the typologies in the personality theory of modern psychology. "The concept of "character" in the encyclopaedia of psychology reflects qualities of human nature that determine and motivate the action of man. ${ }^{10}$ Character is personality evaluated. ${ }^{11}$ This is supported by Saucier and Srivastava that the term "character" tends to be defined more narrowly than personality in which to emphasize volition and morality. ${ }^{12}$ Thus, it can be concluded that, character according to the general definition, is what constitutes the moral part of personality.

To sum up, the definition of personality and character, in general, are slightly different in terms of the aspect that each represents. Character is more related to the aspect of morality in the psychology of personality. Regardless of their difference, both personality and character are influencing factors in determining the quality of an individual's behavior.

\section{Overview of Islamic Character}

Al-Ghazali described character (al-khuluq) as a stable state of the soul, which causes the individual to perform his actions spontaneously and easily, without thought or deliberation. ${ }^{13}$ The author further mentions that Al-Ghazali further clarified that there are three ways in the acquisition of good character (khuluq al-hasan), namely, habituation, learning, and divine generosity. To Al-Ghazali, character is changeable since habituation is considered as the decisive factor in the acquisition of good character. This is applicable for a majority of human virtues that is influenced by the reasoning and revelation later on. Ibn Manzur and Al-Ghazali refer akhlaq as the reflection of internal nature of human that gives special meaning in accordance with their status as created beings and will be expressed through their good or bad characters and behavior. ${ }^{14}$ Akhlaq is crucial to stimulate and guide individuals in performing certain acts which will create a huge and positive impact on organizations. ${ }^{15}$ The brief outline of Islamic character above indicates the importance of every Muslim to internalize and manifest Islamic character within themselves.

\section{Islamic Personality}

It is affirmed that Muslim scholars have always emphasized good personality. One's life actions are directed and inspired by the strong faith in God, which is founded upon the introduced spiritual dimension in the human personality. ${ }^{16}$ This is supported by Tekke, Ismail, Adnan, and Othman who presented that one of the strong predictors of one's closeness to God and remembrance of Him and His Prophet is the Islamic personality. ${ }^{17}$ In the Holy Qur'an, human personality covers all the human aspects which are the spiritual, the moral, the intellectual, the aesthetical, and the physical dimensions. ${ }^{18}$ The word "personality" is not mentioned directly in the Holy Qur'an, instead, it is stated in several terms; man (insan), people (nas), believer (mukmin), unbeliever (kafir), hypocrite (munafiq), and Christians and Jews (ahl al-kitab). ${ }^{10}$ Islam gives merit on personality that involves virtue and good deeds. ${ }^{19}$ This is supported by Tekke, Ismail, Adnan, and Othman that a Muslim should have a good personality, for example, Amanah (Trust) as elucidated in the Holy Qur'an and the Sunnah. ${ }^{17}$ In chapter 2 , verse 25 , Allah says, "But give glad tidings to those who believe and work righteousness, that their portion is Gardens, beneath which rivers flow. Every time they are fed with fruits therefrom, they say: "Why, this is what we were fed with before," for they are given things in similitude; and they have therein companions pure (and holy); and they abide therein (for ever)."3

To sum up, the Islamic personality is a form of moral quality in the psychological aspect of a human, which are governed by the belief in Allah as the One God and Muhammad (Peace be upon him) as His servant and His messenger. These are also seen in the form of spiritual, intellect, aesthetical and physical dimensions in one's real life. A good Muslim should internalise noble attributes, as depicted by Prophet Muhammad in all aspects of their daily work such that these attributes become part of the personality.

\section{Overview of Ethics and Islamic Ethics. Ethics}

There are some variations in understanding what constitutes "ethics". Ethic means the rules of behaviour based on ideas about what is morally good and bad, while ethics is an ii) area of study that deals with ideas about what is good and bad behaviour; a branch of philosophy dealing what is morally right and wrong, ii) a belief that something isimportant (www.merriamwebster.com/dictionary/ ethics). Loeb states that "ethics" originated from the Greek word, "ethos", which means "character, spirit, and attitude of a group of people or culture". ${ }^{20}$ Ethics also represents a set of moral principles, rules of conduct or values. ${ }^{21,22}$ It is relevant when a person has to make a decision from different choices concerning ethical principles. ${ }^{22}$ Ethics has also been defined as the "habits, customs, moral, character, feelings, attitudes and ways of thinking". ${ }^{23}$

Shogar has defined ethics in a different context. Philosophically, the term ethics is used for the 
theoretical study of moral values which aims to understand the nature of human character, source of morality and standards of moral judgments. ${ }^{18}$ Ethics is said to be related to customs, traditions as well as beliefs and worldviews. ${ }^{24}$ The author further argues that being ethical is not following one's feelings or desires, or the standards of behavior (culture) that have been accepted by majority of society. In short, ethics is the ideas about what is morally good and bad that will contribute to the patterns of human behaviors.

\section{Islamic Ethics}

In Islamic teaching, ethics is one of the branches of knowledge about human character. Moosa argues that ethics is synonymous with three forms of knowledge in Islam; akhlaq (good character), adab (right action), and tasawwuf (sufism). ${ }^{25}$ These forms of knowledge circle within the character building towards obtaining the pleasure of God. In the Holy Qur'an, ethics in the sense of wise advice for a good and happy life is the central issue. The author also affirms that the ethical knowledge cannot be attained without revelation because the faith in God is the precondition to establish the meaning of moral values. Halstead interprets akhlaq as 'ethics' or 'moral values', while adab combines two different related ways of understanding good behavior; 1) politeness, courtesy, etiquette, good upbringing, culture, refinement, good breeding and good manners, and 2 ) morality and values. ${ }^{26}$

Islamic ethics is related to several Arabic terms such as, ma'ruf (approved), khayr (goodness), haqq (truth and right), birr (righteousness), qist (equity), 'adl (equilibrium and justice), and taqwa (piety). ${ }^{27}$ Ethics is not simply the religious morality reflected in the performance of some practices such as praying, fasting, and not consuming alcohol, but also covers all aspects of life, physically, morally, spiritually, in secular form, intellectually, emotionally, individually, and collectively. ${ }^{28,29,30}$ In brief, Islamic ethics is concerned with the good deeds that cover all aspects of life as prescribed by the Holy Qur'an and Sunnah.

There are two levels of the Islamic ethics ('ilm alakhlaq) development; 1) the normative discourse, 2 ) the ethical thought and theories. ${ }^{18}$ The author further clarifies that the normative discourse is founded by the Holy Qur'an as the basic premise of Islamic thought, while the practices of the Prophet (peace be upon him) are the primary sources of Islamic ethics and moral values. The ethical thoughts and theories, meanwhile are developed by Muslim scholars, mainly in three fields; 1) moral philosophy which developed by Muslim philosophers and theologians (kalam), 2) personal or juridical ethics as developed by jurists (fuqaha'), and 3) virtues ethics or training of the soul which was mainly concerned by Islamic mysticism (tasawuf). Thus, it can be concluded that the Islamic ethics includes the concepts of akhlaq, adab, and other Muslim scholars' theories and thoughts based on the
Holy Qur'an and Sunnah. These concepts, theories and thoughts are involved in the development of human character.

Therefore, it can be said that Islamic ethics is one of the aspects in Islamic personality since it is related to the processes of character building, which eventually forms the Islamic personality. The discussions about ethics are always in accordance to the belief in Allah as the One God and Prophet Muhammad (Peace be upon him) as His servant and His messenger. In other words, Muslim scholars are always referring to the Holy Qur'an and Sunnah as the main sources to justify what is right or wrong to do.

\section{Overview of Medical Imaging Theory and Practices}

Medical Imaging or Radiography is a subspecialization in the field of Medicine.It is concerned with the production of images of the human anatomy. These images are used to detect, locate, and characterize the medical anomalies. The humanistic component in Medical Imaging involves the task of dealing with people such as the patients and other healthcare practitioners. ${ }^{31}$

Zainuddin summarized that Medical Imaging practice has its contributions in the curative, rehabilitative, and preventive medicine, besides the application of technology and associated procedures. ${ }^{4}$ Other than that, as a part of the field of medicine, Medical Imaging subscribes to accepted principles and doctrines of health care. Observation of beneficence, non-maleficence, autonomy and justice are some of the main characteristics that form the principles of health care as proposed by Beauchamp and Childress (1989). ${ }^{4}$ The earlier author stressed that most of the principles and concepts, which have been professionally accepted, were formulated by those who came from the secular background. There is nothing wrong in adopting and adapting the concepts and principles introduced by the nonMuslim scholars as long as they are parallel to the Islamic teaching. ${ }^{4}$

Discussions addressing the Islamic perspectives of the aspects encountered by Medical imaging practitioners in their professional settings are limited. Zainuddin in his work conceptualized Islamic spirituality in Medical imaging involving the humanistic and technical dimensions of the practitioner, patient care and practices. ${ }^{4}$ In the literature, the author has outlined the overview on the concept of Islamic spirituality in relation to the Medical Imaging practices with the discussions on several cases in point for better understanding of the issues such as the preservation of 'aurah (dignity) and cross-gender patient-practitioner interactions are the examples that are highlighted. Many discussions from western literature have been addressing the spirituality and spiritual needs by clinicians and nurses, especially in the aspects that 
related to death, euthanasia or end of life. ${ }^{32}$ The aspects which are encountered by clinicians and nurses are not normally encountered by Medical imaging practitioners in their professional settings. Thus, efforts need to be directed towards addressing the issues in Medical imaging so that the harmonization between the Islamic values and the principles in Medical imaging practices can be achieved. One of the efforts is by giving emphasis to the aspect of personality in Muslim Medical imaging practitioners. The concepts and principles, which have been introduced by the non-Muslims scholars, can be adopted and adapted into the Muslim practice as long as there is no contradiction with the Islamic teachings.

\section{METHODOLOGY}

The professional personality traits of Medical imaging practitioners were determined by examining the professional guidelines and other literature from the Internet searches / online databases. Keywords that include "medical imaging", "radiography", "code of practice", "best practices", "good practice", "standards of practice", "code of ethics", and "professional attributes" were used to identify relevant articles to support the study. The interactive search platforms of online databases and the use of Boolean operators with "Google" search engine were optimized for the searches. The searches were limited to documents of standards of practice in Medical Imaging in the pdf file type. All available documents that fit the above criteria irrespective of country and professional organizations were included for further examination. The documents were limited to those published in English within the last ten years, 2006-2016.

The contents of the retrieved documents were analyzed for the expected professional attributes. The expected professional attributes were then classified into professional personality traits and then categorized under several domains in Medical imaging. The tabulation of the professional personality traits for this part of the study outlined the professional personality traits that are common in documents from the various countries and organizations.

Efforts were taken to display the data by ranking the traits; from the most frequent trait mentioned in the documents followed by those of lesser mention. This helped in formulating an overall picture of professional personality traits that are expected of Medical imaging practitioners and the application of the traits in the practice. An appropriate discussion followed the examination of the documents.

\section{RESULTS}

Documents from ten Medical imaging organizations were retrieved from the online search. Table 1 below shows the organizations and titles of the documents. The term "item" in the table refers to the number of professional aspects that each document addresses. Meanwhile Table 2 summarizes the statements of the guidelines into general themes. The themes were classified under seven Medical imaging domains. Descriptions were added to describe the applications of the professional personality traits within the related domains in Medical imaging.

Table (i): The Guidelines' number, Organizations, Title, Number of items, Year of publication, and References.

\begin{tabular}{|c|c|c|c|c|}
\hline No. & Organizations & Title of the document & No. of items & Year \\
\hline 1. & $\begin{array}{l}\text { Health and Care Professional } \\
\text { Council (HCPC) (United Kingdom) }\end{array}$ & Standards of Proficiency- Radiographers. ${ }^{33}$ & 15 & 2016 \\
\hline 2. & $\begin{array}{l}\text { American Registry of Radiologic } \\
\text { Technologists (ARRT) (United } \\
\text { States) }\end{array}$ & Standards of Ethics (Code of Ethics). ${ }^{34}$ & 10 & 2015 \\
\hline 3. & $\begin{array}{l}\text { New Zealand: Medical Radiation } \\
\text { Technologists Board (New Zealand) }\end{array}$ & $\begin{array}{l}\text { A Guide for Registered Medical Imaging and } \\
\text { Radiation Therapy. }{ }^{35}\end{array}$ & 9 & 2014 \\
\hline 4. & $\begin{array}{l}\text { Radiographer Registration Board } \\
\text { (RRB)-CORU }\end{array}$ & Code of Professional Conduct and Ethics. ${ }^{36}$ & 23 & 0ct 2013 \\
\hline 3. & $\begin{array}{l}\text { Society of Radiographers (United } \\
\text { Kingdom) }\end{array}$ & Code of Professional Conduct. ${ }^{37}$ & 26 & July 2013 \\
\hline 0. & $\begin{array}{l}\text { The Society of Radiography in } \\
\text { Kenya (SORK)(Kenya) }\end{array}$ & The Code of Conduct and Ethics. ${ }^{38}$ & 18 & April 2012 \\
\hline 1. & $\begin{array}{l}\text { European Federation of } \\
\text { Radiographer Societies (EFRS) }\end{array}$ & Code of Ethics. ${ }^{39}$ & 17 & 2010 \\
\hline 0. & $\begin{array}{l}\text { The Irish Institute of Radiography } \\
\text { and Radiation Therapy (Ireland) }\end{array}$ & $\begin{array}{l}\text { Code of Professional Conduct for Diagnostic } \\
\text { Radiographers and Radiation Therapists. }{ }^{40}\end{array}$ & $\begin{array}{l}19 \text { (Diagnostic } \\
\text { radiographers) }\end{array}$ & 2010 \\
\hline 9. & $\begin{array}{l}\text { Canadian Association of Medical } \\
\text { Radiation Technologists (Canada) }\end{array}$ & $\begin{array}{l}\text { Code of Ethics: Medical Radiation } \\
\text { Technologists. }{ }^{41}\end{array}$ & 31 & June 2008 \\
\hline 10. & $\begin{array}{l}\text { Australian Institute of Radiography } \\
\text { (AlR)(Australia) }\end{array}$ & $\begin{array}{l}\text { Guidelines for Professional Conduct for } \\
\text { Radiographers, Radiation Therapists and } \\
\text { Sonographers. }{ }_{42}\end{array}$ & 11 (Radiographer) & July 2007 \\
\hline
\end{tabular}


Table (ii): Medical Imaging Domains, Professional Traits (Themes), and Its Descriptions.

Medical Imaging Domains Professional Traits (Themes) Descriptions

Professionalism

Patient care

Use of technology

Technicalities or procedures

Safety and Security

Research

Resources Management
Respectful; Safe practice; Safe activity; Equality; Trustworthy; Truthful; Effective communication, Wisdom, Competency, Honesty and Integrity; Teamwork; Self-reflect; Dignity; Responsible and

Accountable; Compassionate, Continuity of Knowledge and skills development; Ethical behaviors; Adhere to laws and regulation; and Being up-to-date.

Respectful; Safe practice, Equality; Trustworthy; Truthful; Effective communication; Wisdom; Honesty and Integrity; Dignity; Responsible and Accountable; Compassionate; Ethical behaviors.

Safe practice; Trustworthy; Truthful; Honesty and Integrity; Adhere to laws and regulations; Being up-to-date.

Safe practice; Trustworthy; Truthful; Honesty and Integrity; Adhere to laws and regulations; Being up-to-date; Teamwork.

Safe practice; Safe activity; Continuity of knowledge and skills development; Adhere to laws and regulations; Being up-to date.

Teamwork; Self-reflection; continuity of knowledge and skills development, Adhere to laws and regulations, Being up-to-date.

Trustworthy; Wisdom; Honesty and Integrity; Teamwork; Continuity of knowledge and skills development.
The professionalism domain focuses on the professional attributes when dealing with the patients, other workers, self and the public. The Medical imaging practitioners are expected to maintain and improve these attributes for keeping the high standard conduct in the profession.

The patient care domain focuses on the professional attributes while dealing with anything related to the patients. The Medical imaging practitioners are expected to maintain and improve these attributes to keep the high standard of care.

The use of technology domain focuses on the professional attributes when dealing any matters related to technological equipments and applications. The Medical imaging practitioners are expected to maintain and improve these attributes to keep high standard of quality.

The technicalities and procedures domain focuses on the professional attributes during facing the matters involving the mechanisms in the preparation and performing the examinations or treatment. The Medical imaging practitioners are expected to maintain and improve these attributes to ensure the high standard of practice.

The safety and security domain focuses on the protection of the safety and security of the patients, workers, self, the public and surroundings. The Medical imaging practitioners are expected to maintain and improve these attributes in order to keep the high security environment.

The research domain focuses on the professional attributes in the matters related to the development and improvement in the profession. The Medical imaging practitioners are expected to maintain and improve these attributes to keep the continuity of the high standard of practice in the profession.

The resources management domain focuses on the professional attributes in managing any resources including the human, financial, facilities, and etc. within the Medical imaging department. The Medical imaging practitioners are expected to maintain and improve these attributes in order to keep the utilization of the present resources optimum. 


\section{DISCUSSION}

This section will discuss on the implications of some of the determined professional personality traits from the Islamic perspective. The harmonization of the Islamic values to the professional personality traits is seen through the alignment of the concepts between these two elements. However, space constrains for this article does not permit a thorough examination of other professional traits to be made. The authors would limit the discussions to selected traits.

There are nineteen common professional personality traits that were determined from the Medical imaging professional guidelines; 1) respectful, 2) safe practice, 3) safe activity, 4) equality, 5) trustworthy, 6) honesty and integrity, 7) truthful, 8) responsible and accountable, 9) compassionate, 10) wisdom, and 11) being up-to-date, 12) competence, 13) teamwork, 14) self-reflection, 15) dignity, 16) ethical behaviors, 17) adhere to laws and regulations, 18) effective communication, and 19) continuity of knowledge and skills development. These professional personality traits were located accordingly under seven domains in Medical imaging; 1) professionalism, 2) patient care, 3) uses of technology, 4) technicalities and procedures, 5) safety and security, 6) research, and 7) resources management.

The obtained professional personality traits from the professional guidelines are actually aligned to Islamic values and morals. For example, the trait of trustworthiness is related to the concept of amanah in Islamic teaching. Amanah is the sense of responsibility, honorable, courtesy, showing optimal result and respectful to others. ${ }^{43}$ Allah mentioned in the Holy Quran, chapter 4, verse 58, "Allah doth command you to render back your Trusts to those to whom they are due; And when ye judge between man and man, that ye judge with justice: Verily how excellent is the teaching which He giveth you! For Allah is He who heareth and seeth all things." This trait is expected to shape the practitioners to perform their practice with full of awareness and sincerity that eventually causes the practitioners to excel in every aspect. The trait of amanah must be infused within every Muslim Medical imaging practitioners so that the aim to have the highest quality of practice can be achieved.

The trait of truthfulness is another important characteristic that must be internalized by a Muslim Medical imaging practitioner. It is called Siddiq in Arabic that means being true to oneself, be honest to others and honest to God, and the belief that one has to fulfill the obligation in order to achieve success now and hereafter. ${ }^{43}$ Allah has mentioned in the Holy Quran, chapter 9, verse 119, "O ye who believe! Fear Allah and be with those who are true (in word and deed)." "This trait will cause the practitioners to be honest in their practice within or without the authority's supervision. It also helps them to perform the responsibilities with the consciousness of the limitation of self, patients and other workers that cause them to practice within the best of their capacity of competency.

Another important professional trait is effective communication, in which to deliver the practice and services with the best language and right speech. This is related to the concept of tabligh. Tabligh is the ability to communicate, being accountable and transparent, able to face pressure and the ability to cooperate and work in harmony. ${ }^{43}$ "Abdullah bin 'Amr bin Al-'As (may Allah be pleased upon them) reported, Rasulullah (Peace be upon him) has said, "Convey from me even an ayah of the Quran..." (Hadith Al-Bukhari). This trait is expected for the practitioners to not only enhance the communication skill, but also open the opportunities to spread the messages of Islam while performing the Medical imaging practices. This is because effective communication can be used as a tool to show the beauty Islam besides to establish collaboration with others.

Wisdom or fatanah includes the intelligence in attitude and knowledge, disciplined, proactive attitude and the ability to make the best decision. ${ }^{43}$ Allah mentions in the Holy Qur'an, chapter 58, verse 11 , “...Allah will rise up, to (suitable) ranks (and degrees), those of you who believe and who have been granted (mystic) Knowledge. And Allah is wellacquainted with all ye do." 3 This trait can be attained through research and sharing knowledge and skills within the organisation. The Medical imaging practitioners should participate in the professional and role development activities so that their competency can be improved. This can also be achieved through the collaboration with the professionals in other fields.

The present authors undertake to address comprehensively the nineteen professional traits in another publication. Suffice to say that the four presented traits; trustworthiness, truthful, effective communication and wisdom, when infused with the Islamic values will show the Islamic foundations in these traits are built upon on Islamic revealed knowledge (the Holy Qur'an and the Sunnah). These traits are vital in order to guide the Muslim Medical imaging practitioner with personal and professional competencies that are based on strong Islamic fundamentals.

\section{CONCLUSION}

This paper is meant to propose a list of Muslim Medical Imaging professional personality traits. This effort is initiated since the existing professionals fail to capture the true attributes of Medical imaging practitioners. The development of the Islamic professional personality as applicable for Muslim Medical imaging practitioners is still at its infancy stage. A lot of effort is required for identification, refinement and validation of the traits, so that others can use it with high level of confidence. Based on the extensive review of the literature, the 
results show nineteen (19) professional personality traits in Medical imaging within seven (7) domains. These professional personality traits are closely related to the Islamic values. The infusion of the Islamic values to the existing Medical imaging professional personality traits is vital to keep the high standard of the practice in the profession from the Islamic heritage. Subsequently, the proposed Medical imaging professional personality traits can be used to assess the attributes of Muslims Medical Imaging practitioners, which are perceived to be important for the improvement within the medical imaging practices.

\section{REFERENCES}

1. Khan MS. Humanism and Islamic education. Muslim Education Quarterly 1987; 4(3): 25-35.

2. Ashraf RM. The Westhill project RE 5-16: Islam: teachers manual. London: Mary Glasgow, 1988.

3. 'Ali AY. The holy qur'an: text and translation. Kuala Lumpur: Islamic Book Trust, 2007.

4. Zainuddin ZI. Aligning Islamic spirituality to medical imaging. Journal of Religion and Health 2015; 54(4): 1-15.

5. Allport GW. Pattern and growth in personality. New York: Holt, Rinehart \& Winston, 1961.

6. Maddi SR. Personality theories: a comparative analysis. Homewood, III: Dorsey Press, 1980.

7. Nabhani TAD. Islamic personality alIslamiyyah. London: Al-Khalifah Publications, 1960.

8. Zidan A. Revitalisation of the sciences of religion: Al-Ghazali's ihya' ulum ad-din. Cairo: Islamic Publising and Distribution, 1997.

9. Ashbrook RM. Character disorder. In: Craighead E, Nemoff CB, eds. The concise corsini encyclopedia of psychology and behavioural science. $3^{\text {rd }}$ ed. New Jersey: John Wiley \& Sons, Inc, 2004.

10. Al- Ammar A, Shamsudin FM, Md.Idris K. Ethics and ethical theories from and Islamic perspective. International Journal of Islamic Thought 2013; 4(Dec): 1-13.

11. Allport GW. Personality: a psychological interpretation. New York, NY: Holt, 1937.

12. Saucier G, Srivastava S. What makes a good structural model of personality? Evaluation the Big Five and alternatives. In: Mikulincer $M$, Shaver PR, Cooper L, Larsen R, eds. Handbook of social and personality psychology. Washington, DC: APA, 2014; 4: 283-305.

13. Sherief MA. Ghazali's theory of virtue. Washington: State University of New York press, 1975.

14. Mat Z, Basir SA, Zanariah J. A study on practice of Islamic professional ethics in shaping an ethical work culture within Malaysian Civil Service Sector. Asian Social Science 2015; 11(17): 28-34.

15. Ibn Miskawayh. Tahdhib al-akhlaq. Beirut: Mansyuwwarat Dar Maktabah al-Hayah, 1961.

16. Mischel W, Shoda Y, Ayduk O. Introduction to personality. $8^{\text {th }}$ ed. United States of America:
John Wiley \& Sons, 2008.

17. Tekke M, Ismail NAH, Adnan MAM, Othman N. Students' Islamic personality on Amanah: a structural modeling approach. Pertanika J. Soc. Sci. \& Hum 2015; 23(1): 129-138.

18. Shogar IAA. The basic structure of ethical norms. IIUM Press: Kuala Lumpur, 2015.

19. Othman AK, Hamzah MI, Hashim N. Conceptualising the Islamic personality model. Procedia-Social and Behavioral Sciences 2014; 130: 114-119.

20. Loeb S. A survey of ethical behavioral in the accounting profession. Journal of Accounting Research 1971; 9(2): 287-306.

21. Rachels J, Rachels S. The elements of moral philosophy. New York: McGraw-Hill, 1993.

22. Hayes R, Schilder A, Dassen R, Wallage P. Principles of auditing: an international perspective. Berkshire: McGraw-Hill Publishing Company, 1999.

23. Bertens K. Etika. Jakarta: Gramedia Pustaka Utama, 2004. [Indonesian].

23. Hashi AA. Islamic ethics: an outline of its principle and scope. Revelation and Science 2011; 1(3): 122-130.

24. Moosa E. "Muslim ethics". In: Schweiker W, eds. The Blackwell companion to religious ethics. Malden: Blackwell, 2005; 237-243.

25. Halstead JM. Islamic values: a distinctive framework for moral education? Journal of Moral Education 2007; 36(3): 283-296.

26. Al-Aidaros A, Shamsudin FM, Md. Idris K. Ethics and ethical theories from an Islamic perspective. International Journal of Islamic Thought 2013; 4(Dec): 1-13.

27. Al-Banna. Messages' group of Imam Hassan alBanna. $1^{\text {st }}$ ed. Alexandria: Darul Al-D'aoah Publication, 1940.

28. Al-Qaradawi Y. The general characteristics of Islam. $9^{\text {th }}$ ed. Beirut: Darul al-Ressalh Publication, 1996.

29. Yaken $\mathrm{F}$. What is the meaning of my belonging to Islam? Beirut: Darul Al-Ressalh Publication, 2006.

30. Zainuddin ZI, Radzi HA. Examining Islamic perspectives in medical imaging literature: a study involving Scopus indexed journals. Revelation and Science 2013; 3(2): 39-50.

31. Zainuddin ZI. Addressing spirituality and spirituality needs in medical imaging. $10^{\text {th }}$ Allied Health Scientific Conference 2014: Transformation of AHP Practices towards excellence 2014; 1 -16.

32. Health and Care Professions Councils (HCPC). Standards of Proficiency- Radiographers [online]. Available at: www.hpcuk.org/assets/.../10000dbdstandards_of_profi ciency_radiographers.pdf. Accessed September 25, 2016.

33. American Registry of Radiologic Technologists (ARRT). Standards of Ethics [online]. Available at: https://www.arrt.org/pdfs/governingdocuments/standards-of-ethics.pdf. Accessed March 10, 2016.

34. New Zealand Medical Technologist Board. A 
Guide for Medical Imaging and Radiation Therapy

[online].Availableat:www.mrtboard.org.nz/... $\mathrm{mrtb} /$.... /MRTB-registered-practitioner-

booklet2.... Accessed September 25, 2016.

35. Radiographer Registration Board (RRB) - CORU. Code of Professional Conduct and Ethics [online]. Available at: www.coru.ie/uploads/.../RRB_Code_of_Profes sional_Conduct_and_Ethics.pdf. Accessed September 25, 2016.

36. Society of Radiographers (SoR). Code of Professional Conduct [online]. Available at: www.sor.org/printpdf/book/export/html/9953 . Accessed September 25, 2016.

37. The Society of Radiography in Kenya (SORK). The Code of Conduct and Ethics [online]. Available at: www.eacc.go.ke/DOCS/codeSORK.pdf. Accessed September 25, 2016.

38. European Federation of Radiographer Societies (EFRS). Code of Ethics [online]. Available at: www.efrs.eu/publications/.../2010_EFRS_code _of_ethics_english_versio... Accessed September 25, 2016.

39. The Irish Institute of Radiography and Radiation Therapists. Code of professional conduct for diagnostic radiographers and radiation therapists [online]. Available at: http: / /www.iirrt.ie/about-us/best-practiceguidelines. Accessed September 25, 2016.

40. Canadian Association of Medical Radiation Technologist (CAMRT). Code of Ethics: Medical Radiation Technologists [online]. Available at: http://www.camrt.ca/mrtprofession/professional-resources/code-ofethics/. Accessed September 25, 2016.

41. Australian Institute of Radiography (AIR). Guidelines for Professional Conduct for Radiographers, Radiation Therapists and Sonographers [online]. Available at: www.air.asn.au/files/01_TheAir/07_Ethics/Pro fessional_Conduct.pdf. Accessed September 25, 2016.

42. Rahman ZA, Md. Shah I. Measuring Islamic spiritual intelligence. Procedia Economics and Finance 2015; 31(2015): 134-139. 